\title{
Lingüística se escribe con A: La perspectiva de género en las ideas sobre el lenguaje Teresa Moure (2021) Madrid: Catarata, 349 pp.
}

\author{
Reviewed by Daniel Amarelo
}

In Lingüistica se escribe con A, Teresa Moure recovers the role of women in linguistics with the concept of historical memory. The aim of her book is to construct an alternative view of linguistics made of nonhegemonic ideas explored by female linguists. Not only does she fill this gap, but she also explains social and academic causes from an interdisciplinary perspective. Exploring the idea that marginalised female scholars have thus dealt with the margins of the discipline - that is, peripheric research areas and linguistic tasks - the author blends feminist perspectives with linguistic historiography. This contribution is released in addition to others that, in the midst of the Covid-19 pandemic, make 2021 a year of review, reflection and practical proposals for the future in this regard (e.g. Ayres-Bennett and Sanson 2021). Also, being written in Spanish, this volume helps to decentralise and move debates on gender and language beyond the Englishspeaking world. With this regard, the book includes scholars and data from a world that speaks Spanish - e.g. María Goiry and María Moliner - as well as some minority and endangered languages (such as Galician, Gujarati and Estonian).

In the first two chapters, the author provides the epistemological and methodological foundations of her approach, which includes peripheral

\footnotetext{
Affiliation

Daniel Amarelo

he/him/his//they/them/their

Department of Spanish and Portuguese, University of Colorado Boulder, USA

email: daniel.amarelo@colorado.edu
} 
methods and linguistic trades such as cryptography (Chapter 3), translation (Chapter 4), primatology (Chapter 5), anthropology (Chapter 6), sociolinguistics (Chapter 7) and the philosophy of language (Chapter 8). She sets out her central argument: the construction of a linguistics canon has excluded women because of their work in peripheral disciplinary research spaces. The cryptographic work of the so-called 'code girls' in the United States, accelerated in times of World War II, exemplifies how what is usually considered 'linguistics' and 'research' neglects strategies such as intuition, creativity or lateral thinking - ways of doing and thinking the author considers to be typically ascribed to the Other (67).

In this 'history of absences', translation is another great concealment. Moure explores a genealogy of concepts such as 'manipulation' or 'quality' in translation theory. In particular, the Quebec Feminist School of Translation (e.g. Susanne de Lotbinière-Harwood, Barbara Godard, Suzanne Jill Levine, etc.) is given a central place through the idea of feminist intervention - that is, the overt linguistic mediation in texts to erase masculinist worldviews and to negotiate meanings through the active role of the translator as a producer. Similarly, primatologists (e.g. Jane Goodall, Dian Fossey, Sue Savage-Rumbaugh and others) provided space for methodological innovation and the application of non-discrete perspectives in linguistics. For instance, zoosemioticians, in their attempts to understand communication between humans and animals, suffered the discredit of the excessive prevailing biologism, brought together by machismo, xenophobia and speciesism. This shows the importance of an intersectional historiographic uprising. Likewise, the trajectories of anthropologists such as Margaret Mead, Ruth Benedict and Gladys Amanda Reichard, if analysed through the lens of Moure's 'deviant' genealogy (163), show the renewal and humanisation of scientific procedures. While introducing theoretical and methodological turns, questioning the general dynamics of the the-hunter and she-gatherer' narrative and exploring Other(ness), they were also victims of the disregard for their work and the exposure of their private lives.

There came a turning point, represented by feminist sociolinguists such as Deborah Tannen, Jennifer Coates and Janet Holmes, especially after the work of Robin Lakoff (1975). It is worth noting how the 'radical feminism of the 1980s' - an academic and activist current born in the Anglophone world, formed of groups with exclusive feminine militancy exploring the ideological power of languages (212) - was followed by the inclusion of sociological and anthropological aspects to language and gender research, which led to new trends of study that are still underway. Moure reviews these trends from the first forays into 'genderlects' and the proposals for the feminisation of language to the contemporary emergence of queer theories. Her own philosophical and intersectional approach contrasts 
with the scientific autonomisation of linguistics as a discipline, which has excluded many philosophers of language from a known linguistics history. Thus, Moure speculates that linguistics could be seen as a subfield of philosophy, in particular revaluing Butler's contributions and her discussion of hate speech (Butler 1997). Similarly, the feminist and postcolonial critiques offered by intercultural linguistics and eco-linguistics (Skutnabb-Kangas 2012) enrich that same epistemological turn.

Furthermore, Moure discusses useful procedures for the inclusion of gender perspectives in the consideration of the history of linguistic ideas. She highlights a collective approach (specifically in Chapters 9 and 10) against the idea of 'individual geniuses'. Chapter 9 in particular questions the 'wife-of' stories in recovery processes (as with Carol Chomsky or Shirley Hockett, for example). In addition, Moure suggests that male camaraderie has made it difficult to trace lines of influence and support among female academics, commonly seen only as disciples. That same feminist 'punto de vista de la multitud [viewpoint of the crowd]' (331) also promotes the inclusion of figures with no linguistic academic training who, regardless, contributed significantly to the field, such as Catherine the Great.

In sum, this is not a book on the history of (some) women who practised linguistics, but a historical review of linguistics and its accounts of hiding. When we think of the field of gender and language, postmodern contemporaneity inevitably comes to mind due to the current strengthening of that field of research. However, Moure's book attempts to erase wellestablished binomials in the discipline (such as diachronic vs synchronic) and contributes to expanding the time frames of poststructuralist feminist perspectives, thus helping to decolonise academic work.

\section{References}

Ayres-Bennett, Wendy and Sanson, Helena (2021) Women in the History of Linguistics. Oxford: Oxford University Press. https://doi.org/10.1093/oso/9780198754954.001.0001

Butler, Judith (1997) Excitable Speech: A Politics of the Performative. New York: Routledge.

Lakoff, Robin (1975) Language and Woman's Place. New York: Harper \& Row. Skutnabb-Kangas, Tove (2012) Linguistic Genocide in Education: Or Worldwide Diversity and Human Rights? New York: Routledge.

https://doi.org/10.4324/9781410605191 